Indonesian Journal of Global Health Research

Volume 3 Number 3, August 2021, pp. 389 - 398

e-ISSN 2715-1972; p-ISSN 2714-9749

http://jurnal.globalhealthsciencegroup.com/index.php/IJGHR

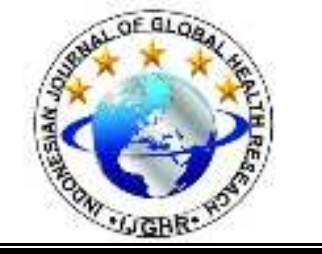

\title{
ANALYSIS OF THE COMPETENCY-BASED CLINICAL NURSE CAREER PATH DEVELOPMENT SYSTEM IMPLEMENTATION
}

\author{
Elisabeth Longge*, Rina Anindita, Rian Adi Pamungkas \\ Master of Hospital Administration, Universitas Esa Unggul, Jl. Arjuna Utara No.9, RT.1/RW.2, Duri Kepa, Kec. \\ Kb. Jeruk, Kota Jakarta Barat, Jakarta 11510, Indonesia \\ *longgeelisabeth@gmail.com
}

\begin{abstract}
Nurses are one of important human resources in a hospital and are one of the keys to the successful implementation of services in the hospital. Providing opportunities in the form of career development is very important for the hospital to organize. The purpose of this study was to analyze the gap between the level of importance and implementation of career development at the UKI hospital in terms of the management and nurse executives perceptions. This research is a quantitative and qualitative research. The results of the study found that the negative average gap (-0.09) between the level of importance and implementation in terms of management and nurse perceptions was low. Based on the results of the study, it was concluded that the gap between the level of importance and implementation at the UKI Hospital judging from the management and nurses perception was still in the fair category. The research result can be used as material for reference and the study in the field of nursing science, particularly in the field of nursing management related to perceptions of career development with the quality of hospital services.
\end{abstract}

Keywords: career development; competence; clinical nurse

\begin{tabular}{|c|c|c|}
\hline $\begin{array}{c}\text { First Received } \\
\text { 14 July } 2021 \\
\end{array}$ & $\begin{array}{c}\text { Revised } \\
\text { 20 July } 2021\end{array}$ & $\begin{array}{c}\text { Accepted } \\
28 \text { July } 2021\end{array}$ \\
\hline $\begin{array}{c}\text { Final Proof Received } \\
27 \text { August } 2021\end{array}$ & & $\begin{array}{c}\text { Published } \\
28 \text { August } 2021\end{array}$ \\
\hline $\begin{array}{l}\text { How to cite (in APA style) } \\
\text { Longge, E., Anindita, R., \& Pamung } \\
\text { Path Development System Impleme } \\
\text { https://doi.org/10.37287/ijghr.v3i3.5 }\end{array}$ & $\begin{array}{l}\text { 2021). Analysi } \\
\text { Indonesian Jo }\end{array}$ & $\begin{array}{l}\text { petency-Based Clinical Nurse Career } \\
\text { bal Health Research, 3(3), 389-398. }\end{array}$ \\
\hline
\end{tabular}

\section{INTRODUCTION}

The main task of health care facilities is to provide quality and safe health services for the community. There were 376,701 nurses recorded as the largest number of health workers out of 1,246,164 total health workers based on BPPSDM health data for 2019 (Bppsdmk.kemkes.go.id). A hospital must improve the quality of its services, including the quality of human resources (HR) as a way to deal with competition for health services between countries and technological advances. Nurses are a vital resource in the hospital and one of the keys to the success of services in the hospital. This is because nurses are the largest number of resources in the hospital and have more interactions with patients. The role of nurses in achieving hospital goals includes trying to make the hospital where they work towards an international standard hospital through professional services and quality services.

Based on PMK No.40 of 2017, it is known that hospital health service institutions are one of the parties responsible for fostering nurses and are obliged to provide equal opportunities for them to develop their career paths as nurses. The career path development referred to here is continuous professional development by following formal education, training, research, community service, workshops or seminars and recognition of their abilities based on work experience and performance of nursing practice. Research aimed at examining the evaluation of the application of the career path system has not been widely used. One of the studies conducted by Saragih \& Lala (2013) shows that of the 228 nurses at the St. Borromeus hospital, some respondents found that there were $(55.7 \%)$ nurses who had inappropriate career paths, which resulted in low levels of job satisfaction. A small 
proportion of them admitted that the workload that PK I did was not comparable to the salary received by PK II or III, even though they had exercised the authority that PK II or III should have done. The mismatch of salary with this task load is one of the sources of PK I dissatisfaction. The results of research conducted by Kusumah et.el, (2019) at Dr. Lung Hospital. H. A. Rotinsulu Bandung found that the implementation of competencies based on the professional career path of nurses is already in the appropriate category. which is $58.1 \%$. The implementation of career paths by Clinical Nurses I $(56.3 \%)$ was also found to be appropriate, as were Clinical Nurses II (50.0\%) and Clinical Nurses III (66.7\%). Reviewing the results of Saparwati and Mutinik's (2017) research at Tugurejo Hospital Semarang, it was found that most nurses had a poor perception of the mechanism for advancing the career path of nurses represented by a percentage of $58.2 \%$. These findings indicate that nurses still do not have a deeper understanding of the mechanism for advancing a nurse's career path.

Even though it has been implemented, but judging from the initial data obtained regarding the development of a nursing career path at the UKI general hospital, there are still some aspects that are not in accordance with the standards in determining PK I to PK V. The determination of a nurse's career path at the UKI Hospital some are still based on the reward system for class positions with DP3 assessment, even though in general, DP3 cannot be used in assessing and measuring how much the productivity and contribution of employees to the organization. The importance of advancing the career ladder of nurses according to PMK RI policy No 40 of 2017 is aimed at increasing the motivation of nursing staff so that they can improve their performance in providing nursing care.

Based on the background that has been described, this study aims to analyze the gap between the level of importance and the implementation of career development at UKI Hospital in terms of management and nurse perceptions. The significance of this research is that it can contribute to the science of hospital management, especially in the field of nursing management, in the implementation of a professional clinical nurse career path development system.

\section{METHOD}

This research is a mix methods research with sequential explanatory. This is done using two methods drawn from two different approaches, namely sequential quantitative and qualitative approaches. The first stage is carried out using quantitative methods while in the second stage the analysis is carried out using qualitative mehods to confirm quantitative data. Data collection was carried out by distributing questionnaires and in-depth interviews with management and clinical nurses. The sample in this study was 36 samples selected using purposive sampling technique using inclusion and exclusion criteria. The data were then collected and analyzed using Wilcoxon's non-paramatic test, method of importance performance analysis (IPA) and descriptive analysis. This test aims to analyze the gap between the level of importance and the implementation of career development at the UKI Hospital seen from the perceptions of management and nurses.

\section{RESULTS \\ GAP analysis}

Based on the calculation of the gap between the level of importance and the implementation of nursing career development at UKI Hospital, in terms of nursing management, a positive number was obtained with a positive mean of 0.31 . These results indicate that the expectations and reality in the implementation of career development are appropriate. However, in terms of clinical nurse management, the calculation of the gap between the level of importance and implementation of nurse career development at UKI Hospital shows a negative number where the average value is obtained (-0.4). These findings indicate that expectations and realities in the implementation of career development are not appropriate. On the other hand, it was found that there was a difference between the level of importance and the level of implementation of nursing career development at UKI Hospital with a value of -0.09 based on the calculation of the difference in GAP. 
Table 1

Respondent Characteristics

\begin{tabular}{|c|c|c|c|c|}
\hline \multirow[t]{2}{*}{ Variable } & \multicolumn{2}{|c|}{ Nursing Management } & \multicolumn{2}{|c|}{ Clinical Nurse } \\
\hline & f & $\%$ & $\mathrm{f}$ & $\%$ \\
\hline \multicolumn{5}{|l|}{ Gender } \\
\hline Male & 1 & 5.6 & 2 & 11.1 \\
\hline Women & 17 & 94.4 & 16 & 88.9 \\
\hline \multicolumn{5}{|l|}{ Age } \\
\hline 20-30 years & 0 & 0 & 3 & 16.7 \\
\hline $31-40$ years & 3 & 16.7 & 11 & 61.1 \\
\hline $41-50$ years & 15 & 83.3 & 4 & 22.2 \\
\hline \multicolumn{5}{|l|}{ Education } \\
\hline D3 Kep & 0 & 0 & 12 & 66.7 \\
\hline S1 Ners & 18 & 100 & 6 & 33.3 \\
\hline S2 Kep & 0 & 0 & 0 & 0 \\
\hline \multicolumn{5}{|l|}{ Career Path } \\
\hline PK I & 0 & 0 & 2 & 11.1 \\
\hline PK II & 5 & 27.8 & 8 & 44.5 \\
\hline PK III & 2 & 11.1 & 3 & 16.7 \\
\hline Gol III/a & 1 & 5.6 & 1 & 5.6 \\
\hline Gol III/b & 6 & 33.3 & 2 & 11.1 \\
\hline Gol III/c & 2 & 22.1 & 1 & 5.6 \\
\hline Gol III/d & 1 & 5.6 & 1 & 5.6 \\
\hline Gol IV/a & 1 & 5.6 & 0 & 0 \\
\hline \multicolumn{5}{|c|}{ Length of Work } \\
\hline$>1$ th & 0 & 0 & 3 & 22.2 \\
\hline $6-10$ th & 2 & 11.1 & 9 & 50 \\
\hline $11-15$ th & 1 & 5.6 & 0 & 0 \\
\hline$>15$ th & 15 & 83.3 & 3 & 16.7 \\
\hline
\end{tabular}

Table 2

Average GAP beetwen the Level of Importance and the Implemnetation of Nursing Career Development

\begin{tabular}{lcccc}
\hline Career Development & Mean Importance & Mean Performance & Gap & Result \\
\hline Management & 3,02 & 3,34 & 0,31 & Positive \\
\hline Clinical Nurse & 3,49 & 3,08 & $-0,40$ & Negative \\
\hline Average & 3,25 & 3,21 & -0.09 & Negative \\
\hline
\end{tabular}

\section{Importance Performance Analysis}

Priority mapping analysis was carried out on all respondents in this study. Data processing was carried out using SPSS version 21.0. It was obtained the results in the form of IPA Cartesian diagram for all management and nurse respondents on the implementation of the clinical nurse career path development system based on competence which is as follows: 


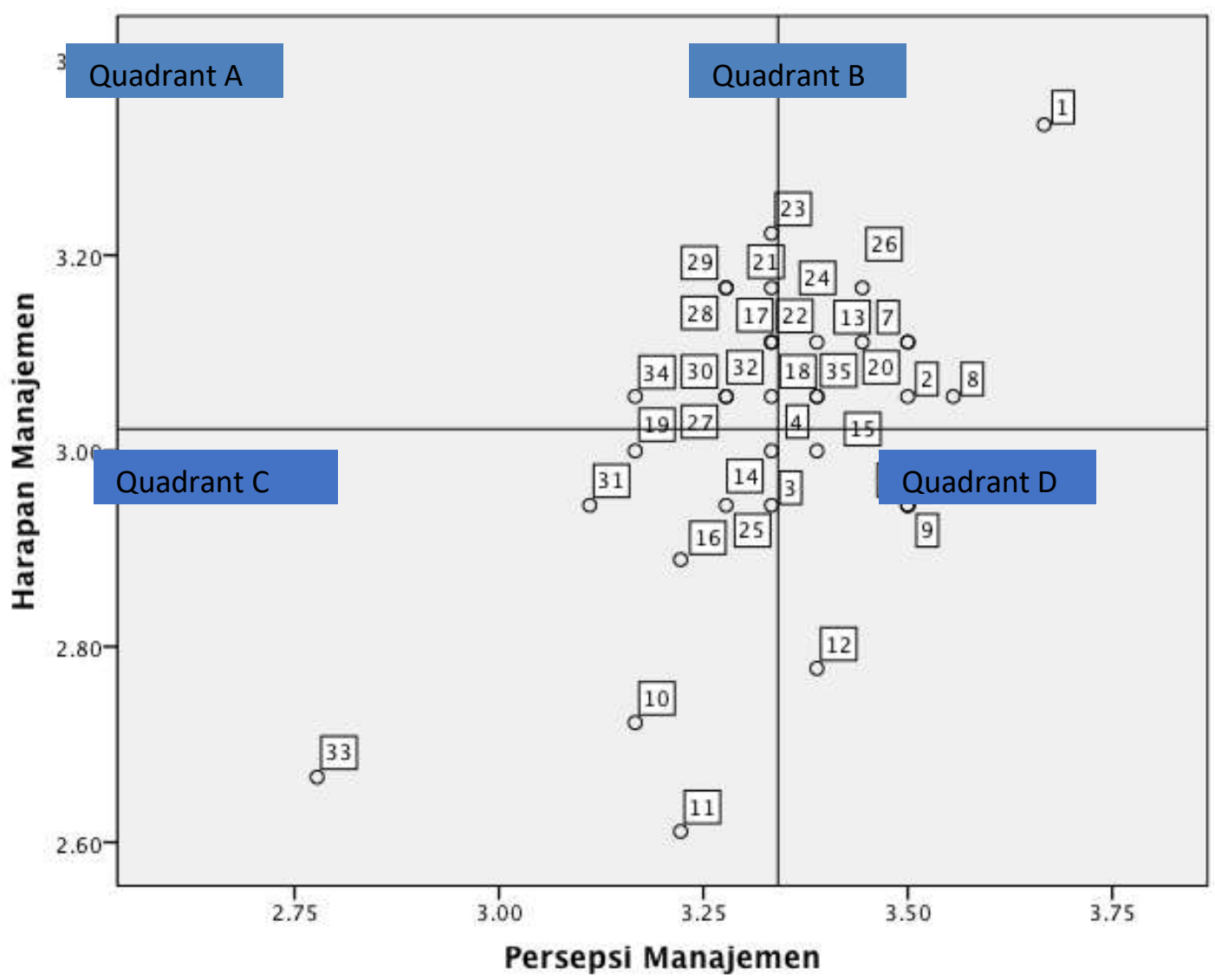

From the description of Figure 1, the Cartesian diagram shows that nine (9) attributes are in quadrant $\mathrm{A}$, ten (10) attributes are in quadrant $\mathrm{B}$, ten (9) attributes are in quadrant $\mathrm{C}$, and six (6) attributes are in quadrant D.

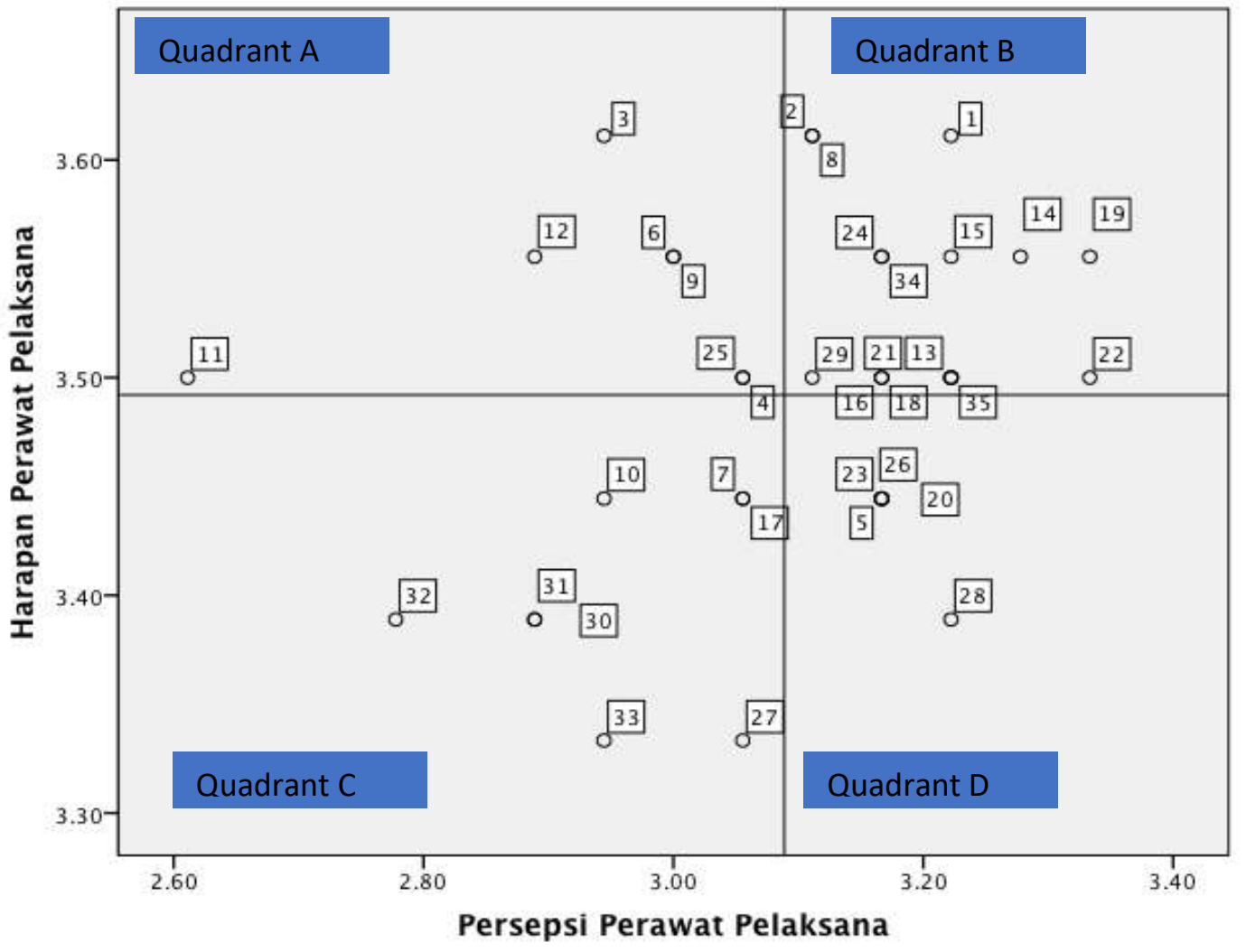


Regarding the implementation of the nursing career path that is felt by the clinical nurse, it can be seen in the cartesus image above. The figure shows that according to the respondent, most of the attributes are mostly in the B quadrant, namely fifteen attributes, seven (7) attributes in quadrant A, eight (8) attributes in quadrant $\mathrm{C}$, and five (5) attributes in quadrant D.

\section{Quadrant A}

The attributes that are located in quadrant A are very crucial attributes that require immediate follow-up.

\section{Quadrant B}

The attributes located in this quadrant are considered quite good and enough to be maintained.

\section{Quadrant C}

The attributes which are located in this quadrant are attributes that do not need special attention much.

\section{Quadrant D}

Attributes located in this quadrant are considered less important, so that management needs to allocate resources related to these attributes to other attributes that have higher priority for handling.

There are several items in this study that need to be maintained on the similarity of perceptions between management and nurses, namely in the B quadrant, including:

1. Item 1: Career path is an effective way to recognize the talents / skills of nurses in nursing services

2. Item 2: UKI Hospital Management helps in adjusting career needs.

3. Item 8: Management of UKI Hospital provides equal opportunities in career

4. Item 13: The peer-to-peer nursing assessment process at the career level is an effective way to evaluate how well the nurse's performance standards are.

5. Item 18: Standards for each level of the nursing career path accurately reflect the practice of nursing at their level.

6. Item 24: Assessment process at career level is an effective way to evaluate how well the nurse's performance standards are.

7. Item 35: Advancement at the career path level encourages nurses to become role models by applying advanced clinical practice concepts to improve the quality of nursing care they provide.

The things that need to be improved in quadrant $\mathrm{A}$ is the level of importance and implementation are:

1. The environment created by the career ladder level encourages nurses to accept responsibility and accountability for clinical practice (item 17).

2. The career path level effectively encourages nurses to engage in activities that directly affect their patients' care abilities (item 21)

3. Expectations from each level of career path for nurses are reviewed / reassessed to ensure that the nurse understand well what is expected from them (item 22)

4. Work expectations for the nurse level at the career level clearly and accurately describe the work that nurses do (23)

5. When nurses progress to feel at the next career level, they are expected to provide care to clients with greater complexity and intensity needs (27). 
6. Nurses are encouraged to work and achieve advancement at career level (28)

7. Nurses believe that advancement at career level is valued by fellow nurses (29)

8. Career paths provide appropriate promotional opportunities while nurses are in clinical practice (30)9

9. Advancement at the career level provides a sense of achievement and professional satisfaction in a nursing career (32)

10. Career advancement encourages nurses to use their own initiative and judgment in providing nursing care (34)

11. The superior always pay special attention to the career development of nurses (3)

12. The management of UKI Hospital prepares a position or career of a nurse in accordance with the performance being carried out, namely increasing the level from Clinical Nurse 1 to Clinical Nurse V or based on class according to competency standards (4)

13. The management of RSU UKI provides work facilities in accordance with the given position (6)

14. Management of UKI Hospital provides information on career needs (9)

15. Evaluation of nurses' portfolios using career path performance standards is fair and equitable (25)

16. Hospital management provides position recognition and greater service rewards to high achieving nurses (11)

17. UKI Hospital Management transfers and places employees in their positions (12)

There are several things were found related to the development of career patterns at UKI Hospital based on the results of interviews with representatives of several respondents between the clinical nurses and the nursing management, namely as follows:

1. The implementation of a career pattern development system has actually been carried out, but there are still some inconsistencies with experience and educational background in terms of determining Clinical Nurses and giving rewards.

2. There were respondents who stated that it was unfair in the distribution of training related to differences in perceptions of nurses and management in equitable distribution of training to nurses, even though management stated that everything was regulated fairly.

3. Giving rewards in developing career patterns is still done with DP3, which is related to the payroll system in developing career patterns of nurses who are still constrained by costs.

4. The mechanism implemented in the UKI Hospital regarding the career development pattern of clinical nurses based on competence has not been running well and is still focused only on administration in terms of achieving accreditation of hospital and is still in the stage of reform.

5. The positive changes have not been maximized where the rewards given are small. Specifically, the promotion of position has not been carried out well.

\section{DISCUSSION}

1. The Difference Between Perception of Management and Perception of Nurses in Career Development at UKI Hospital.

Based on finding with Wilcoxon analysis in hypothesis testing, it indicated that there was no difference between the perceptions of management and implementing nurses in the implementation of the clinical nurse career path development system in accordance with the competence at UKI Hospital, which was seen from the sig value of 0.338 was greater than 0.005. Management and implementing nurses had the same perception on the career development pattern of clinical nurses at UKI Hospital. 
According to Priyono and Maris (2008) career development is a formal approach that organizations take to ensure that people with the right qualifications and experience are available when they are needed. Therefore, it is clear that the implementation of nursing career development at UKI Hospital is a system to improve performance and professionalism, it is in line with the field of work through competency enhancement that results in professional performance.

2. The Perception of Management on the Implementation of Career Development in UKI Hospital.

In general, the results of this research revealed that the perception of management on the implementation of nursing career path development at UKI Hospital. The mean value of management's perception on the implementation was $\mathrm{m}=3.34$. This indicated that the perception of management regarding the implementation of nursing career path development at UKI Hospital was good due to the average showed an appropriate opinion regarding to the implementation of career paths. When it has been viewed from the statement each respondent, it showed the same mean value. In accordance with Andrew J. Dubrin (1982) the purpose of career development is to assist in achieving corporate goals and individual, employee welfare, assisting employees to realize potential abilities, strengthening relationships between employees and companies, proving social responsibility. In the implementation of career development, according to the perception of management, career development is generally appropriate. Therefore, it needs to be improved, and gradually adjusts to the regulations from the government.

3. The Perception of Management on the Importance of Career Development at UKI Hospital.

Generally, the finding indicated that the perception of management on the importance on nursing career development at UKI Hospital. The mean value of management's perception of the importance of career development at UKI Hospital was 3.02. This indicated that the perception of management on the importance of career development at the UKI Hospital was an essential. According to PMK RI No. 40 of 2017, organizing the implementation of a nursing career path involves several related elements, namely the hospital leadership, the head of the nursing field and the nursing committee. One of the roles and functions of each related unit is to consider and approve financing in the context of implementing a career path of nurse at the hospital. This must be a consideration of the relevant officials for the running of the career path development system of nurse at the UKI Hospital so that the quality of nursing services is guaranteed.

4. The Perception of Nurses on the Implementation of Career Development at UKI Hospital. The finding indicated that the mean value of the perceptions of nurses on the implementation of career development at UKI Hospital was 3.08. In general, the results of this study showed that the perception of nurses regarding the implementation of the development of a nurse's career path at UKI Hospital was good due to the average indicated an appropriate opinion on the implementation of career paths. In accordance with Siagian (2012) indicators that need to be considered in career development are fair treatment in a career, concern for superiors, information about various promotion opportunities and levels of satisfaction. Therefore, the implementation of career paths at the UKI Hospital, although on the whole based on perception is appropriate because the mean obtained is 3.08, it is still necessary to improve management regarding to the implementation of a nurse's career path in order to create comfort and satisfaction and also provide quality services.

5. The Perception of Nurses on the Importance of Career Development at UKI Hospital. 
In general, the finding revealed that the perceptions of nurses on the importance of nursing career development at UKI Hospital. The mean value of nurses' perceptions on the importance of career development at UKI Hospital was 3.49. This indicated that the perception of nurses on the importance of career development at UKI Hospital was very essential. In accordance with PMK RI No. 40 of 2017, the mechanism for implementing the professional career path system in hospitals has implementation stages, namely from recruitment and selection, orientation, internship, competency assessment, determination of clinical authority and advancement of career paths. It is expected that the management of the UKI Hospital needs to pay attention to related mechanisms, and it needs to be applied to the nurse in UKI Hospital. The success of providing nursing care by nurses needs to be supported by a mechanism for improving the professionalism of nurses, one of which is through nursing career development.

6. GAP or Gap between the Level of Interest and Implementation of Career Development. The overall average GAP between the level of interest and the implementation of career development for nurses at UKI Hospital was -0.09 with an average value of importance level (3.25) was greater than the level of implementation (3.21) This indicated that the implementation of the nurse career path development system as the executor at the UKI Hospital still needed the improvement. According to Bernardin (2008) an indicator that needs to be considered in career development is fair treatment in a career. This fair treatment can only be realized if the criteria for promotion are based on objective, rational and widely known considerations among employees. Besides, the concern of the supervisor is that employees crave their supervisors to involve directly in their respective career planning so that employees know the potential that needs to be addressed. Information about various promotions, employees generally expect that they have access to information about various opportunities to be promoted. If the access is absent or very limited so then nurses assume that principles of fairness and equity and opportunity to be considered, to be promoted not being applied. Although in general it can be argued that everyone wants to achieve progress in their career, the measure of success used is different. The level of gap between the level of importance and the level of implementation at the UKI Hospital must be improved in order to

\section{CONCLUSIONS}

The gap found between the level of importance and the implementation of career development in the UKI Hospital in terms of the perception of management nurses and nurses is still considered appropriate. However, the hospital is considered needs to further increase support for nurses and find out what factors may affect nurse satisfaction at work. Assessment based on nursing management related to nurse's expectations is that the hospital must identify the various needs of nurses that are needed in the development of a career pathway system in the future. There are still many improvements should be made in implementing the nursing career path development system at UKI Hospital. The Cartesian diagram obtained from the analysis results also shows that there are several factors included in quadrant A where these factors are the main priority improvements that must be implemented immediately according to the nurse's expectations. The reason is because these factors are considered very important factors, but the practice is still not as expected.

\section{REFERENCES}

Azhari, Riza dan Abdul Halim Wicaksono. (2017) Manajemen Pembinaan Sumber Daya Manusia dalam Pendidikan Islam. Jurnal At-Ta'dib Vol 12 No 2.

Azwar, Hidayah, Andi dan Syamsiah Raul (2019) Career Path to Nurse Job Satisfaction In The Hospital. Journal of Health Science and Prevention Special Issue Desember 2019 ISSN 2459-919x. 
Afriani, Hariyati dan Dewi Gayatri (2017) Dukungan Atasan dan Teman Sejawat Mempengaruhi Ekspektasi Perawat dalam Penerapan Jenjang Karir. Jurnal Keperawatan Indonesia Vol 20. No. 2.

Bppsdmk. kemkes.go.id. Badan PPSDM Kesehatan Informasi SDM Kesehatan.

Bernardin, H. John and Joyce, E.A. Russel. 2008. Human Resource Management. Alih Bahasa Diana Hertati, Mc. Graw Hill, Inc. Singapura

Casto Michelle (2000) Get Smart about Modern Career Development, Atlanta.

Handoko, T. Hani.(2000). Manajemen Personalia dan Sumber Daya Manusia, Yogyakarta: $\mathrm{BPF}$

ICN (2009). Nursing Matter: Infection Control. Fact Sheet. Jenewa, Swiss

International Council of Nurses, 2009. ICN Framework Of Disaster Nursing Competencie. ICN dan WHO Western Pasific Region.

Indrayani Susila. (2016). Analysis of Factors Associated With Desire to Move Work Nurse Hospital X Balikpapan, Year 2014. Jurnal ARSI Vol2. No.2.

J. Dubrin Andrew (1982)Human Resources Management. California: Kent Publising Company.

Kornela, Febi K., Tatong Hariyanto, dan Arhwinda Pusparahaju. (2014). Pengembangan Model Jenjang Karir Perawat Klinik di Unit Rawat Inap Rumah Sakit. Jurnal Kedokteran Brawijaya, Vol 28 Suplemen No.1.

Kusumah, Nugraha Adi Ramdani, Richa Noprianty dan Laelasari. (2019). Evaluasi Pelaksanaan Kompetensi Berdasarkan Jenjang Karir Profesional Perawat. Jurnal Kesehatan Vokasional, Vol 4 No. 2

Nelson, J. M., \& Cook, P. F. (2008). Evaluation of a career ladder program in an ambulatory care environment. Nursing Economics.

Nursalam (2008). Manajemen Keperawatan, Salemba Medika.

Nugraha, Ahyar Yuniawan. (2017). Implementasi Importance And Performance Analysis (IPA) Dalam Pelaksanaan Penilaian Kinerja Karyawan PNS. Diponegoro Journal Of Management, Vol 6 No.4

Peraturan Menteri Kesehatan Republik Indonesia No. 40 Tahun 2017 tentang Pengembangan Jenjang Karir Profesional Perawat Klinis.

PPNI Indonesia. (2005). Standar Kompetensi Perawat Indonesia. dari PPNI Indonesia website: http://www.inna-ppni.or.id

Priyono dan Marnis.(2008), Manajemen Sumber Daya Manusia, Zifatama Publisher

Peruniak Geoffrey. (2010). A Quality of Life Approach To Career Development, Toronto Buffalo London 
Pasang, Kadar dan Rosdiana Natzir. (2015). Nurses Perceptions And Expectation On The Implementation Of Career Ladder In Public Hospitals In Makasar. Indonesian Contemporary Nursing Journal, 2(1), 30-37

Potter,PA and Perry,AG (2014), Clinical Nursing Skill \& Techniques, $8^{\text {th }}$ edition, st Louis

Riyanto, Slamet dan Aglis Andhita Hatmawan (2012), Metode Riset Penelitian Kuantitatif, Deepublish.

Rivai, Veitzal. (2003), Manajemen Sumber Daya Manusia untuk Perusahaan: Dari Teori ke Praktik. Jakarta: PT.Rajagrafindo Persada.

Saragih, S. G., \& Lala, A. (2013). Hubungan jenjang karir dengan kepuasan kerja perawat di Rumah Sakit Santo Borromeus. E-Journal STIKES Santo Borromeus.

Sulistyawaty, Wiwin.,Roro Tutik Sri Hariyati \& Kuntarti. (2016). Implementasi Sistem Jenjang Karir Dalam Pelaksanaan Discharge Planning. Jurnal Ilmu Keperawatan, :vol:4, No 1 .

Shaputra, Rahayu Angga dan Susi Hendriani. (2015). Pengaruh Kompetensi, Komitment, dan Pengembangan Karir Terhadap Kinerja Karyawan PT. Bank Rakyat Indonesia (Persero) Kantor Wilayah Pekan Baru. Jurnal Tepak Manajemen Bisnis Vol VII. No 1.

Sausan dan Muhamad Yusuf (2020). Jenjang Karir Perawat di Rumah Sakit Umum Daerah Meurexa Kota Banda Aceh. JIM FKep Volume IV No.2.

Sinaga, Emiliana Tarigan dan Agustinus Bandur (2019). The Mixed-Methods Study of Nursing Perception on Organizational Culture and Turnover in Hospital. Indonesian Journal of Health Research, 2019 vol.2, No 2, 49-59.

Suparwati dan Mutinik ( 2017) Persepsi Perawat Tentang Jenjang Karir Di RSUD Tgurejo Semarang. Jurnal SMART Keperawatan Vol. 4 No. 2 Desember 2017.

Sarwono Jonathan (2011). Mix Method: Cara Menggabung Riset Kuantitatif dan Riset Kualitatif Secara Benar. Pt Elex Media Komputindo, Jakarta.

Siagian, Sondang P. (2015). Manajemen Sumber Daya Manusia. Jakarta: PT Bumi Aksara

Wahana Komputer (2009).Menguasai Java Programing. Semarang: Salemba 4

Wahyudi, Bambang. (2007). Manajemen Sumber Daya Manusia, Sulita, Bandung.

Zakaria. (2010). Analisis Hubungan Harapan Karier Perawat Pelaksana Dengan Prestasi Kerja DI RSUD Swadana Jombang. Jurnal EDU Health, VOL. 1, No 1, September 2010.

Wahyudi, Bambang. (2007). Manajemen Sumber Daya Manusia, Sulita, Bandung 